\title{
Understanding geohazards in the UNESCO WHL site of the Derwent Valley Mills (UK) using geological and remote sensing data
}

Francesca Cigna, Anna Harrison, Deodato Tapete, Kathryn Lee

Francesca Cigna, Anna Harrison, Deodato Tapete, Kathryn Lee, "Understanding geohazards in the UNESCO WHL site of the Derwent Valley Mills (UK) using geological and remote sensing data ," Proc. SPIE 9688, Fourth International Conference on Remote Sensing and Geoinformation of the Environment (RSCy2016), 96881V (12 August 2016); doi: $10.1117 / 12.2240848$ 


\title{
Understanding geohazards in the UNESCO WHL site of the Derwent Valley Mills (UK) using geological and remote sensing data
}

\author{
Francesca Cigna*a ${ }^{\mathrm{a}}$, Anna Harrison ${ }^{\mathrm{a}}$, Deodato Tapete ${ }^{\mathrm{a}}$, Kathryn Lee ${ }^{\mathrm{a}}$ \\ ${ }^{a}$ British Geological Survey (BGS), Natural Environment Research Council (NERC), \\ Nicker Hill, NG12 5GG Keyworth, United Kingdom
}

\begin{abstract}
An analysis of the British Geological Survey's key hazard datasets (GeoSure, DiGMapGB, National Landslide Database, Geological Indicators of Flooding and Susceptibility to Groundwater Flooding) has provided an enhanced understanding of geohazards within the Core Area and Buffer Zone of the UNESCO Derwent Valley Mills World Heritage List (WHL) site, UK. This knowledge contributes to the preservation of this industrial heritage site that is included as the UK demonstration site of the Joint Programming Initiative on Cultural Heritage and Global Change (JPI-CH) Heritage Plus project PROTHEGO: 'PROTection of European cultural HEritage from GeO-hazards' which is mapping geohazards in the 400+ WHL sites of Europe using satellite radar interferometry (InSAR) combined with geological information. Acting as baseline geohazard characterisation to feed into PROTHEGO's WP5-WP6, our analysis reveals that flooding from fluvial water flow and emergence of groundwater at the ground surface (across over $50 \%$ and $40 \%$ of the Core Area, respectively) are the main geohazards that require careful consideration, together with slope instability along the steep sides of the Derwent river valley (e.g. $1.4 \mathrm{~km}^{2}$ landslide deposits found at Cromford within the Buffer Zone). The UK Climate Projections 2009 (UKCP09) for the Derwent river catchment suggest drier summers (e.g. -15.1 to -19.4\% change in summer precipitation in $2050 ;-18.5$ to $-23.1 \%$ in 2080), wetter winters and increased annual temperatures (e.g. +2.4 to $+2.5{ }^{\circ} \mathrm{C}$ in $2050 ;+3.4$ to $+3.5{ }^{\circ} \mathrm{C}$ in 2080 ) under a medium greenhouse gas emission scenario. These could exacerbate flooding and slope instability and extend the areas susceptible to geohazards, posing further challenges for heritage management.
\end{abstract}

Keywords: geohazards, ground instability, UNESCO, heritage, climate change, flooding, InSAR, remote sensing

\section{INTRODUCTION}

UNESCO's List of World Heritage in Danger that was established in 1972 under the World Heritage Convention encompasses a number of World Heritage List (WHL) cultural and natural heritage sites that are faced with threats by armed conflict and war, earthquakes and other natural disasters, pollution, uncontrolled urbanisation and unchecked tourist development which could have negative effects on the value of the heritage assets [1].

Although in Europe only the WHL sites of Liverpool Maritime Mercantile City in the UK and the Medieval Monuments in Kosovo are inscribed on this list due to urban development and post-conflict instability respectively, there are other threats to the European WHL sites that might affect their state of conservation. These come from natural hazards and geological processes such as landslides, flooding, soil erosion and land subsidence [2], all of which could be exacerbated by climate change in the future.

In this work, we analyse the British Geological Survey (BGS)'s datasets such as GeoSure, DiGMapGB mass movement, National Landslide Database, Geological Indicators of Flooding and Susceptibility to Groundwater Flooding to retrieve an enhanced understanding of geohazards such as slope instability, subsidence and flooding in the UNESCO WHL site of the Derwent Valley Mills in the UK. This work builds upon the geohazard assessment that the BGS is carrying out for the UK WHL sites using its nationwide geohazard data and geological information [3].

The Derwent Valley Mills is one of the demonstration sites of the project PROTHEGO: 'PROTection of European cultural HEritage from GeO-hazards' [4], funded in the framework of the Joint Programming Initiative on Cultural Heritage and Global Change (JPI-CH) Heritage Plus.

* fcigna@bgs.ac.uk; phone +44 115936 3551; fax +44 1159363446

Fourth International Conf. on Remote Sensing and Geoinformation of the Environment (RSCy2016), edited by Kyriacos Themistocleous et al., Proc. of SPIE Vol. 9688, 96990X · ( T) The Author(s).

Published under a Creative Commons Attribution CC-BY 3.0 License $\cdot$ doi: 10.1117/12.2240768 
The project is led by the Italian Institute for Environmental Protection and Research (ISPRA) in collaboration with the UK's Natural Environment Research Council (NERC) as represented by BGS, Cyprus University of Technology (CUT), the University of Milano-Bicocca (UNIMIB) and the Geological Survey of Spain (IGME).

Over its 2.5 year duration, PROTHEGO aims to map geohazards in the 400+ WHL sites of Europe using satellite radar interferometry (InSAR) and other non-invasive remote sensing methods and surveying technologies (e.g. UAV and LiDAR) combined with geological and geomorphological information and, for the demonstration sites, local scale monitoring and advanced modelling.

In this context, the knowledge gathered through this work will act as a baseline environmental characterisation for PROTHEGO's Work Packages (WP) 5 and 6 looking at assessing, monitoring and modelling geohazards that might affect the heritage assets in the Derwent Valley Mills WHL site at the local scale. These WPs will contribute to providing important information feeding into future plans for the conservation and preservation of this site in the future.

\subsection{Cultural and industrial landscape of the Derwent Valley Mills}

The UNESCO Derwent Valley Mills World Heritage Site (DVMWHS) is located in Derbyshire in central England and encompasses a c. $24 \mathrm{~km}$ long stretch of the lower course of the Derwent river valley, from Derby in the south to Matlock Bath in the north where it almost abuts the southern boundary of the Peak District National Park (Figure 1a).
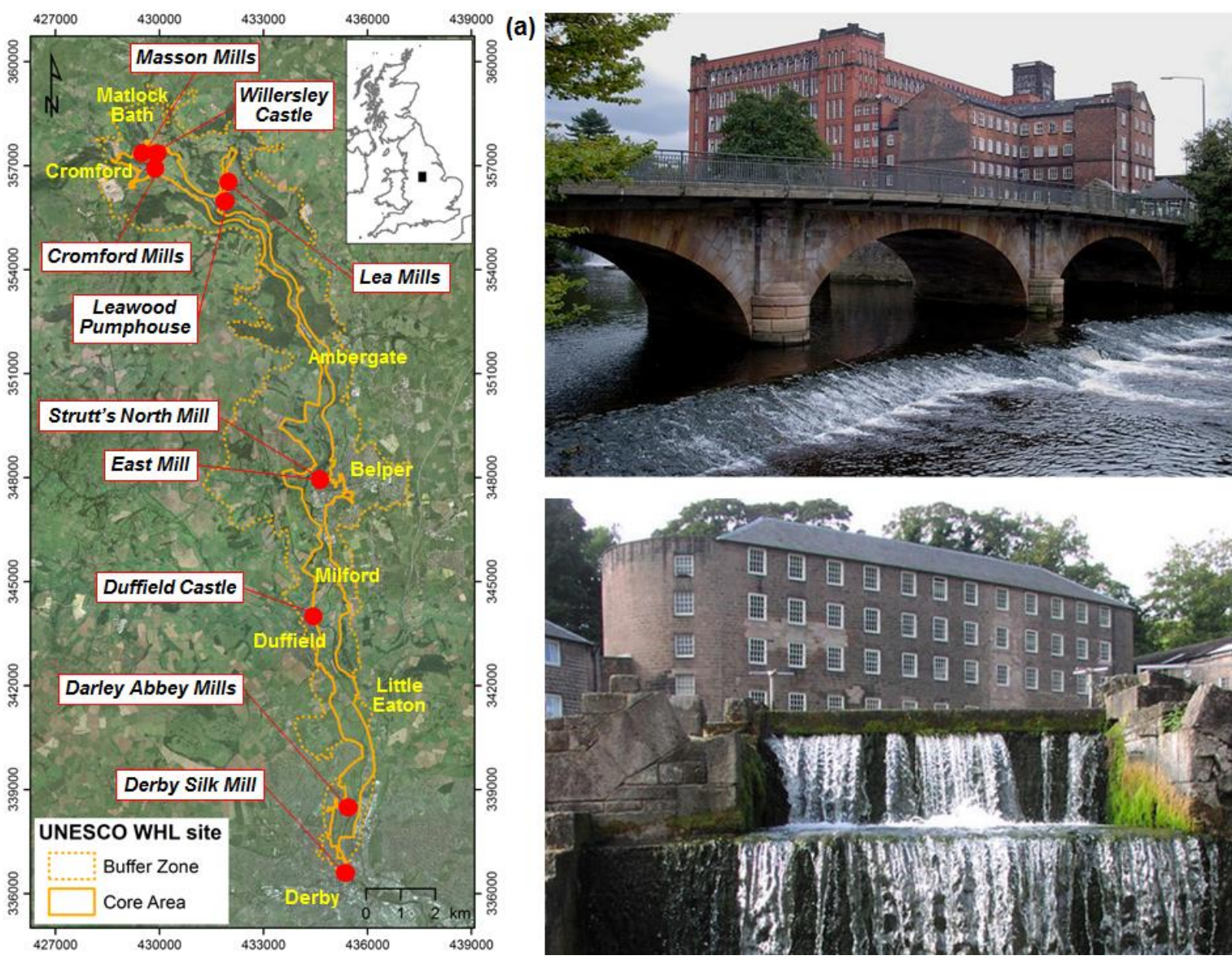

(b)

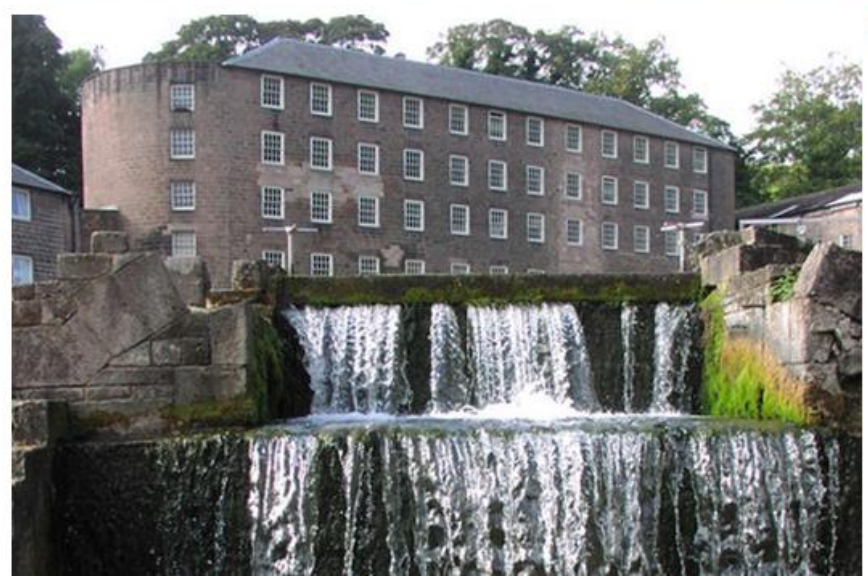

(c)

Figure 1. (a) Core Area and Buffer Zone boundaries of the Derwent Valley Mills UNESCO WHL site with indication of key World Heritage buildings and mill complexes, overlapped onto aerial photography. Map units: British National Grid; projection: Transverse Mercator; datum: OSGB 1936 [WHL site boundaries (C Historic England 2015; Contains Ordnance Survey data (C) Crown copyright and database right 2015; Aerial Photography (C) UKP/Getmapping Licence no UKP2006/01]; (b) Strutt's North Mill, East Mill and road bridge in Belper, seen from River Derwent path; and (c) Cromford Mills [source: http://www.geograph.org.uk; Photographers: (b) D. Bevis; and (c) J. Thomas]. 
The DVMWHS is one of the key sites of Britain's industrial revolution ( $18^{\text {th }}$ century) and was added to the UNESCO WHL in 2001 due to its international role in the birth of the modern factory system, the development of new technology for spinning cotton and first modern industrial settlements, e.g. Cromford, Belper and Milford [5] (UNESCO Ref. 1030; WHL inscription criteria: ii and iv [6]).

The property comprises a largely rural, industrial landscape with a number of historic cotton mill complexes (e.g. Strutt's North Mills and East Mills, Masson Mills, Cromford Mills, Darley Abbey Mills and Derby Silk Mill; Figure 1b-c), the watercourses that powered them, railways, housing settlements and other facilities developed for the mill-worker communities during the $18^{\text {th }}$ and $19^{\text {th }}$ centuries.

The heritage assets within the UNESCO site are protected through a variety of UK planning and conservation laws, and since 2010 the site is managed by the DVMWHS Management Board, a locally-based partnership funded by the Local Authorities, particularly Derbyshire County Council. The DVMWHS Management Plan defines the vision for the site, analyses issues and opportunities facing the property, and defines a programme for 2014-2019 "to maintain the Outstanding Universal Value of the site by protecting, conserving, presenting and enhancing its unique culture, heritage, economy and landscape" [5].

The boundary of the property (namely the 'Core Area') was outlined in 1999 and encloses an area of $12.29 \mathrm{~km}^{2}$ with an associated 'Buffer Zone' of $43.63 \mathrm{~km}^{2}$. The Core Area is a single entity (i.e. polygon), without detailed outlying elements (historic buildings, features and landscapes), linked by linear features where these were the defining characteristic of the historic topography and contributed to the universal value of the site. The outlined boundary, wherever possible, coincided with existing statutory and formal designations within administrative areas where relevant to the inscription criteria, and tests of authenticity were applied in relation to the historical evolution of the cultural landscape. The majority of the buffer zone is defined by the organic landscape of wooded slopes and valleys, whilst other areas are more open and ordered in character, such as moorlands and gritstone heathland [7].

Among some of the different categories of statutory and other designations, the site comprises the whole or part of: (i) 13 Conservation Areas within the Core Area, (ii) 3 Sites of Special Scientific Interest, (iii) 848 buildings inscribed on the List of Buildings of Special Architectural or Historical Interest within the Core Area and Buffer Zone, (iv) 5 Regionally Important Geological Sites, and (v) 9 Scheduled Ancient Monuments (SAMS). These represent key assets to focus the geohazard assessment at local scale within the UNESCO site.

\subsection{Physiographical and geological setting}

The DVMWHS Core Area and Buffer Zone are characterised by elevations ranging between $45 \mathrm{mOD}$ and $325 \mathrm{mOD}$, observed in the south and the north of the WHL respectively (Figure 2a).

An incised gorge at Matlock Bath (in the north of the DVMWHS) and a relatively narrow valley floor to the south towards the confluence with the River Trent define the topography over which the mill complexes and housing infrastructure developed in the $18^{\text {th }}$ and $19^{\text {th }}$ centuries. Whilst the infrastructure associated with the mills are adjacent to the river, villages and towns for the mill workers are situated on higher terraces along the valley sides, away from floodprone areas.

The DVMWHS area is dominated by Quaternary superficial deposits (head, alluvium and river terraces) consisting of clay, silt, sand and gravel, which lie along the River Derwent valley floor.

The underlying bedrock predominantly consists of thick interbedded mudstone, siltstone and sandstone of the Millstone Grit Group (Carboniferous) through much of the central part of the DVMWHS area (Figure 2b). The oldest rocks in the area are of Mississippian age (limestone with sandstone and mudstones) and only outcrop in the northernmost part of the site around Matlock Bath and Cromford. These are overlain by the Bowland High and Craven Groups (interbedded mudstones, siltstones and sandstones), with small outcrops in both the northern and southern parts of the site. It is these interbedded, alternating permeable and impermeable rocks that can frequently give rise to landslide susceptibility, especially so if the river undercuts the toe of the steep-sided slopes (see section 2). Younger Triassic rocks are found underlying the flatter, southernmost part of the site, around Derby.

Over the last two centuries most of the industrial landscape and complexes have been well-preserved and the upper reaches of the valley are still intact, however, present and future environmental and geological processes could expose these heritage assets to a series of threats (see section 2.3), including surface water and fluvial flooding, contaminated sediment transport and remobilisation of deposits/minerals historic mining activities [8]. 


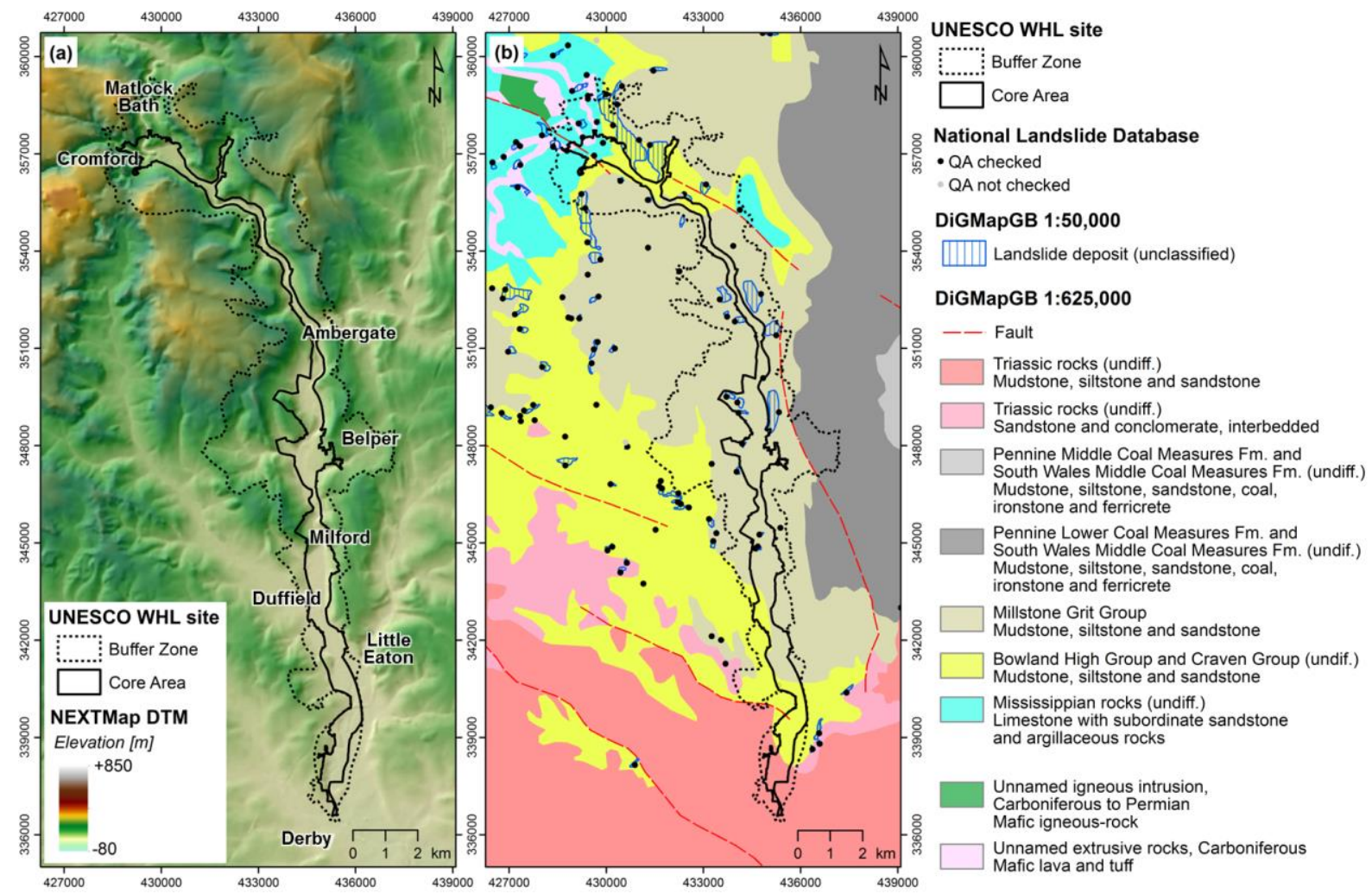

Figure 2. Derwent Valley Mills UNESCO WHL site boundaries overlapped onto: (a) NEXTMap digital terrain model and shaded relief at $10 \mathrm{~m}$ resolution; and (b) bedrock geology from BGS DiGMapGB at 1:625,000 scale, with indication of landslide deposits from BGS DiGMapGB at 1:50,000 scale and records from BGS National Landslide Database. Map units: British National Grid; projection: Transverse Mercator; datum: OSGB 1936 [WHL site boundaries (C) Historic England 2015; Contains Ordnance Survey data (C) Crown copyright and database right 2015; NEXTMap® Britain elevation data () Intermap Technologies; Geological materials @ N NERC. All rights reserved].

\section{GEOHAZARD MAPPING}

\subsection{Input datasets}

Remote sensing data used for this work include $0.25 \mathrm{~m}$ resolution aerial photographs used as the base map for geospatial location of geological and geohazard attributes (Figure 1), and $5 \mathrm{~m}$ resolution NEXTMap® Britain digital terrain model [9] used to understand the topography of the valley and surrounding slopes (Figure 2a).

To identify the geohazards affecting the DVMWHS the following geological, topographic and geospatial layers are available to the BGS: Digital Geological Map of Great Britain (DiGMapGB) at 1:625,000 to 1:50,000 scales [10] (Figure 2b); Engineering Properties Dataset (DiGMapGB-Plus), in particular Corrosivity [11] and Sulfate and Sulfide Potential [12]; Ordnance Survey (OS) topographic maps at 1:10,000-1:50,000 scales; the National Landslide Database (NLD) [13]; Geological Indicators of Flooding (GIF) [14]; Susceptibility to Groundwater Flooding (GWF) [15]; and the six GeoSure datasets: compressible ground, collapsible deposits, landslides, running sand, shrink-swell and ground dissolution [16]. Some of these are analysed and compared in this work, whilst the remainder will be the focus of further studies that the BGS will undertake in the framework of PROTHEGO.

With the exception of OS topographic maps, all the above datasets were developed at BGS as vector polygons at 1:50,000 scale (unless otherwise stated) and searches against them should be done with a minimum $50 \mathrm{~m}$ buffer. 
The BGS products are concerned with natural features and only examine natural geological conditions that leave an area exposed to a certain hazard. Therefore, manmade factors are typically not accounted for, except for the Compressible Ground hazard layer included in GeoSure which does consider manmade ground (e.g. landfill).

To analyse geohazards in the DVMWHS, DiGMapGB at 1:50,000 scale was used as the primary geological reference map to draw the geologic and tectonic setting (see section 1.2) and to assess the extent of mass movements and landslide deposits mapped in the area during surveys from the 1960s to date. This information was integrated with the entries recorded in the NDL by which each landslide is identified by an ID number and a point location (Figure $2 b$ ) denoting the recorded presence of a landslide (within a range of accuracy). Where possible, the location of each point coincides with the highest point on the landslide backscarp feature. Given the geomorphology of the DVMWHS and the presence of steep slopes, landslide susceptibility is among the key geohazard factors to account for.

The Landslides layer part of the GeoSure ground stability dataset also provides landslide susceptibility information according to a scale from A to E where "Class A" means that slope instability problems are not thought to occur and "Class E" that these problems are almost certainly present and may be active.

Given the riverine environment the DVMWHS, susceptibility to fluvial flooding is a key geohazard that requires careful consideration. BGS' GIF data show the areas susceptible to the first influx of flood waters (Zone 1 - higher susceptibility), those susceptible in extreme or prolonged flood events (Zone 2 - lower susceptibility) and areas where no geological indicators of flooding are found. Although they relate to the natural geological conditions only, GIF data are highly informative of the environmental conditions predisposing flooding from rivers that urban development, anthropogenic modifications of the landscape and architectural or infrastructure barriers might worsen. This geological knowledge might therefore inform future decisions on planning and land management.

BGS' GWF data was also analysed to account for the flooding component due to emergence of groundwater at the ground surface. As being a susceptibility dataset, GWF classifies "A" those areas with limited potential for groundwater flooding to occur, "B" those where property situated below ground might be flooded during periods of extended intense rainfall, and " $\mathrm{C}$ " those areas where groundwater flooding can occur at surface. Areas not classified coincide with rock types that are not considered to be prone to groundwater flooding and therefore the GWF classification is not applicable.

\subsection{Methodology}

All the geohazard and geological datasets reported in section 2.1 were analysed individually to assess the spatial distribution of the recorded parameter or information against the official boundaries of the DVMWHS.

As recalled in section 1.1, the DVMWHS is defined by the Core Area and the Buffer Zone. The latter embraces the former in order to protect the setting of the designated site from any development which would damage it [5] and geographically extends across the nearby countryside, also following and being defined in some areas by the topography of the steep sides of the river valley (Figure 2a).

Statistics were extracted for both the official UNESCO boundaries to compare the exposure to geohazards and how it varies spatially depending on the physical boundaries used. We calculate the relative percentages of the areal coverage of each geological feature or hazard class, alongside the predominant class observed within the boundary. For those datasets such as GeoSure that have associated a score system, the 'maximum class' as the class indicating the worst susceptibility scenario to a certain hazard was also computed. As a second level of geospatial assessment, individual layers were analysed in combination to identify spatial correlations. In section 2.3 an example is discussed with regard to GeoSure Landslides layer, the NDL and DiGMapGB-50 mass movements.

Further details of the employed methodology and discussion on multi-property UNESCO WHL sites are reported in [3].

\subsection{Hazard ratings}

Figure 3 compares statistics based on GIF, GWF and GeoSure Landslides layers between the Core Area and Buffer Zone and provides an overall view of the ratings related to some of the main geohazards that the DVMWHS could be susceptible to and might be further exacerbated in future climate change scenarios (see section 2.4).

GIF Fluvial Zone 1 and GWF class $\mathrm{C}$ are the maximum and predominant geohazard classes within the Core Area, while opposite figures are found in the Buffer Zone. Almost 95\% of the Buffer Zone does not show geological indicators of flooding and half of it has limited potential for groundwater flooding to occur based on rock type and estimated groundwater level. 
As expected given the riverine environmental context, GIF Fluvial Zone 1 polygons within the Core Area are coincident with the Holocene alluvium and the geological deposits of the narrow floodplain surrounding both sides of the River Derwent. Although very limited in spatial distribution, the location of Fluvial Zone 1 polygons within the Buffer Zone highlight areas of interest such as the streams Black Brook and Lumb Brooks situated west of Belper Bridge and the stream Coppice Brook in Belper. Other areas that might require consideration are Duffield and the southern part of the DVMWHS Buffer Zone, close to the city of Derby.

These are also areas where the GWF C class polygons concentrate, meaning that during periods of extended intense rainfall groundwater flooding might occur and manifest at surface inundating above-ground properties. Further locations across the Core Area where GWF polygons are scored " $\mathrm{C}$ " to " $\mathrm{B}$ " include Belper Bridge, Ambergate, Whatstandwell and Cromford.

The probability that slope instability might occur is increasingly relevant as the geospatial analysis extends from the Core Area to the Buffer Zone, i.e. when moving from the narrow valley of the River Derwent to the wooded slopes and moorlands facing east and west into the valley. GeoSure classes D and E account together for up to $8 \%$ over the total extent of the Core Area, while they nearly double up to a total value of $16 \%$ across the Buffer Zone (Figure $3 \mathrm{c}$ ). In particular, the increase of class $\mathrm{E}$ of about 5\% reflects the concentration of areas susceptible to slope instability located within the Buffer Zone, in some cases in close proximity to the Core Area boundary, as observed for instance in Cromford and Cromford Mill.

In this area, high spatial correlation is found with the landslide deposits recorded DiGMapGB-50 mass movements. Four entries with total extent of 1,442,628 $\mathrm{m}^{2}$ are mapped north and east of Cromford Mill (see also black dots in Figure $2 \mathrm{~b}$ ). The same correlation is also observed north of Belper Bridge and in Belper, not only within the Buffer Zone, but also within the Core Area. This would suggest that this type of geohazard would require careful consideration in this section of the DVMWHS.

(a) Geological Indicators of Flooding
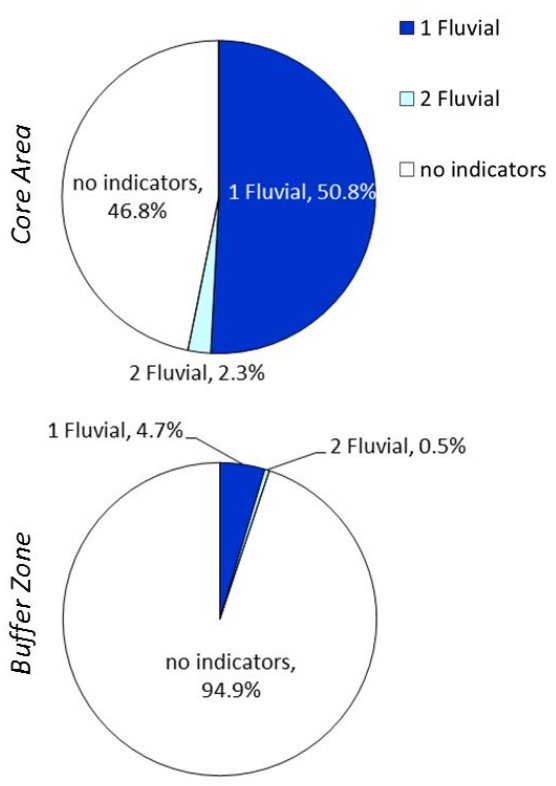

(b) Susceptibility to Groundwater Flooding
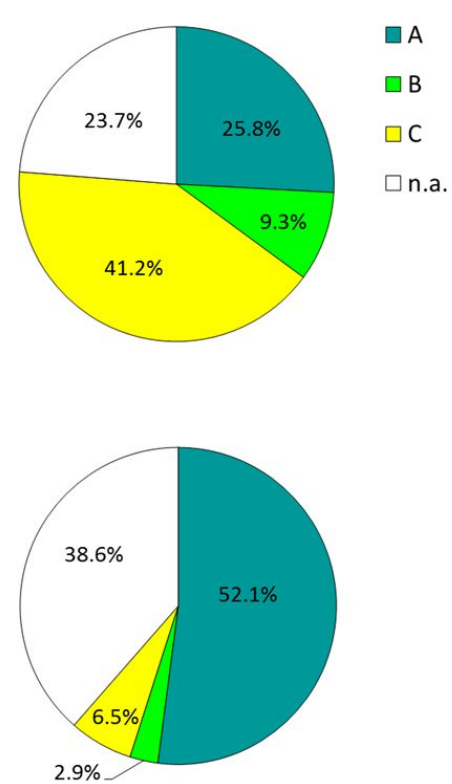

(c) Landslide susceptibility
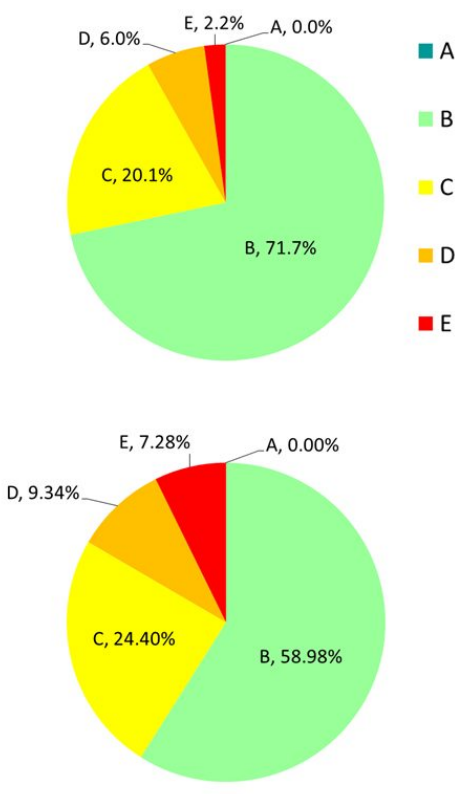

Figure 3 Pie-charts showing the relative areal coverage of hazard classes within the UNESCO DVMWHS Core Area and Buffer Zone based on the BGS datasets: (a) Geological Indicators of Flooding - GIF [14]; (b) Susceptibility to Groundwater Flooding [15]; and (c) GeoSure Slope Instability layer [16]. Refer to the text for the legend notation. 


\subsection{Climate change scenarios}

The UK Climate Projections 09 (UKCP09) provide a range of projections for future climate change for low, medium and high levels of greenhouse gas emissions for the coming century [17]. These probabilistic projections are derived from the results of thousands of runs by a set of climate models. The central estimate identifies the change point where half of the models projected a value below, and half above.

The UKCP09 projections are available in a $25 \mathrm{~km}$ grid square resolution for the UK via the UKCP09 User Interface, as shown in Figure 4 for the Derwent River catchment at the confluence with the River Trent, within which DVMWHS is located. Since the creation of emission scenarios in 2000 [18], observed emissions have most closely resembled the more carbon intensive, medium and high emissions scenarios; therefore making them the most appropriate to investigate [19].

At both the medium and high emissions scenarios and the 2050s and 2080s time periods, the Derwent catchment central estimates are projected to experience: drier warmer summers, wetter winters, similar annual precipitation (Table 1) and higher intensity winter rainfall events.

Some spatial variations in these projections can be seen (Figure 4). In general, the highest increases in summer temperatures are projected to be within the Core Area and Buffer Zone, and the lowest increases are projected to be in the Peak District in the north of the catchment. Similarly, the largest decreases in summer precipitation are projected in the Core Area and Buffer Zone, and the smallest decreases in the Peak District in the north of the catchment. When analysing the UKCP09 projections it is essential to consider the whole of the Derbyshire Derwent catchment as the UNESCO site lies in the lower reaches of the catchment which will therefore be affected and influenced by catchmentwide changes and processes.

A recent English Heritage funded project focussed upon 'better disaster planning and building in resilience for heritage' analysed the evidence of past climate change in the Derwent Valley [20], [8]. Research included assessment of historical, geomorphological and environmental datasets to assess landscape evolution within the catchment and UNESCO WHS boundaries. This was complemented with numerical modelling to identify areas potentially vulnerable to climate change in the future.

The Assessment of Heritage at Risk from Environmental Threat report [21] introduced key threats considered by heritage practitioners to present the most serious and potentially sudden and catastrophic effects on the historic environment, to aid disaster planning. Coastal processes, inland water inundation, extremes of wetting and drying, fire, pests and diseases, and urban heat islands are considered the key threats. Landslides are also highlighted, in the context of coastal processes. The report also recognises climate change as a "threat multiplier".

Of the key threats, those of most relevance to PROTHEGO and the DVMWHS specifically, are:

- Landslides: Shallow translational and rotational landslides are strongly controlled by antecedent effective rainfall, with significant increases in susceptibility following a high intensity rainfall event [22]. UKCP09 projects winter high intensity rainfall events will increase in magnitude by approximately $10 \%$ under both medium and high emissions scenarios [17], leading to increased susceptibility to associated landslide-prone areas.

- Inland Flooding: Flooding is similarly controlled by antecedent soil moisture capacities and rainfall intensities and durations. The projected increased intensity of winter rainfall events [17], implies increased susceptibility to flash flooding in the future. The location of the mills within the landscape, and proximity to the River Derwent, make them particularly susceptible to erosion and flooding as a result of high flow rates associated with high intensity rainfall events.

- Subsidence: Ground movement, due to clay shrink swell, is controlled by variations in soil moisture, driven primarily by rainfall [23]. The drier weather and increased summer temperatures (and the associated enhanced evaporation and evapotranspiration) projected in the climate scenarios, will exacerbate drying out. This could result in lower soil moisture levels developing at increasing depths than currently experienced, leading to increased shrinkage (volume change potential) of clay-rich geological deposits. Consequently subsidence impacts to buildings and infrastructure might occur (see section 2). The historic foundations of some of the mills and associated infrastructure in the Derwent Valley Mills (built in the $18^{\text {th }}$ and $19^{\text {th }}$ centuries) are potentially shallow and, if so, might have difficulties withstanding the enhanced ground movement that may occur through climate change. This could lead to an increasing vulnerability to subsidence hazards. 

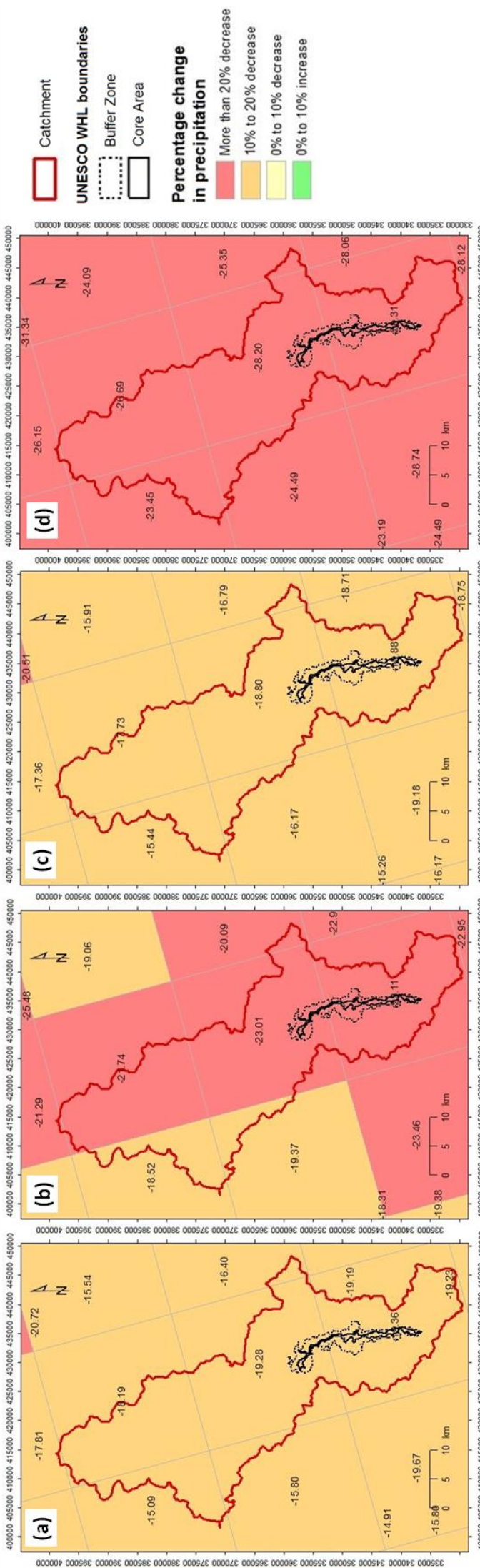
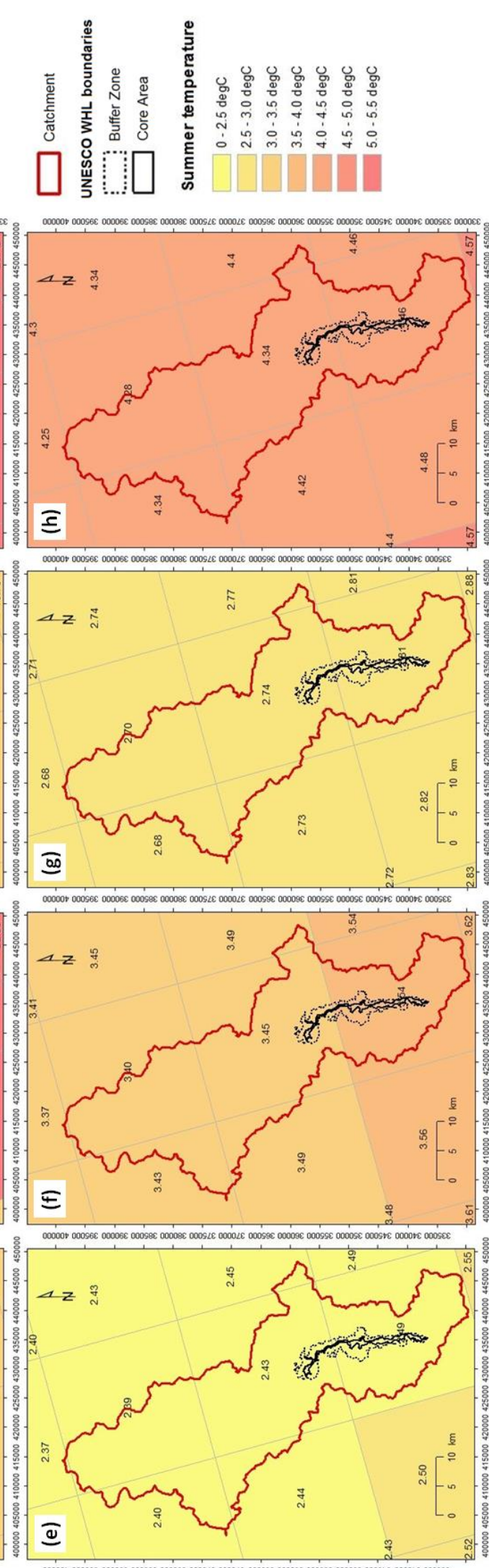

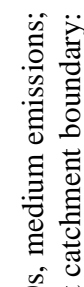

客

ㄱํ

ใิ

is

흘

色

丰

离

它氖

(0)

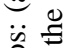

할

ల్ల

Ð

옹

辛

矛

:

㓟

仓ी

च

웜

起

을

ठํํㅇ

의

के

동

s

क

t)

옹

三已

물

of is

U.

.

के

월.

s

유

유 ()

吉 哭焉 
Table 1. Minimum and maximum change in summer precipitation, summer mean temperature and annual mean precipitation from present day conditions based upon the UKCP09 projections [17] for the Derwent river catchment area.

\begin{tabular}{|c|c|c|c|c|c|c|c|c|}
\hline $\begin{array}{c}\text { UKCP09 } \\
\text { projections }\end{array}$ & \multicolumn{2}{c|}{$\begin{array}{c}\text { Central estimate } \\
\mathbf{2 0 5 0} \text { medium emissions }\end{array}$} & \multicolumn{2}{c|}{$\begin{array}{c}\text { Central estimate } \\
\mathbf{2 0 5 0} \text { high emissions }\end{array}$} & $\begin{array}{c}\text { Central estimate } \\
\mathbf{2 0 8 0} \text { medium emissions }\end{array}$ & \multicolumn{2}{c|}{$\begin{array}{c}\text { Central estimate } \\
\mathbf{2 0 8 0} \text { high emissions }\end{array}$} \\
\cline { 2 - 8 } & Min change & Max change & Min change & Max change & Min change & Max change & Min change & Max change \\
\hline $\begin{array}{c}\text { Summer } \\
\text { precipitation } \\
(\% \text { change) }\end{array}$ & -15.1 & -19.4 & -15.4 & -18.9 & -18.5 & -23.1 & -23.4 & -29.3 \\
\hline $\begin{array}{c}\text { Summer mean } \\
\text { temperature } \\
\left({ }^{\circ} \text { C) }\right.\end{array}$ & 2.4 & 2.5 & 2.7 & 2.8 & 3.4 & 3.5 & 4.2 & 4.5 \\
\hline $\begin{array}{c}\text { Annual mean } \\
\text { precipitation } \\
(\% \text { change })\end{array}$ & 0.1 & -0.1 & -1.5 & -2.0 & -0.2 & 0.5 & 0.3 & 0.6 \\
\hline
\end{tabular}

\section{CONCLUSIONS}

This preliminary assessment of geohazards within the DVMWHS boundaries will act as the baseline for BGS to run the local scale monitoring and advanced modelling of the site as part of PROTHEGO's WP5 and WP6.

At this stage the analysis reveals that flooding from fluvial water flow (e.g. for over $50 \%$ of the Core Area) and emergence of groundwater at the surface (e.g. for over $40 \%$ of the Core Area) are the main geohazards that require careful consideration, together with slope instability along the steep sides of the Derwent river valley (e.g. $1.4 \mathrm{~km}^{2}$ landslide deposits found in the Buffer Zone at Cromford). Assessment of geohazards within the Buffer Zone in our methodological approach is crucial since within much of this area slope instability is mapped and a number of abandoned mine workings are present, potentially posing significant threats to the Core Area and key heritage assets.

The DVMWHS has also the potential to experience increased geohazards in the coming decades if the climate is similar to the UKCP09 projections under medium or high greenhouse gas emission scenarios. Climate change projections therefore need to be accounted for to assess potential future threats to the heritage properties, to inform mitigation and resilience planning for the future.

\section{ACKNOWLEDGEMENTS}

This work is funded to the British Geological Survey (BGS) under the Arts and Humanities Research Council (AHRC) Standard Grant ref.: AH/N504361/1 (Principal Investigator: Dr F. Cigna). The authors publish with the permission of the Executive Director of BGS, Natural Environment Research Council (NERC). Russell Lawley at BGS is acknowledged for his insightful comments on the manuscript. More information about the JPI-CH project PROTHEGO can be accessed at: http://www.prothego.eu. The Historic England GIS data were obtained on 14/10/2015; the most publicly available upto-date Historic England GIS data can be obtained from http://www.historicengland.org.uk. The UK Climate Projections (UKCP09) were made available by the Department for Environment, Food and Rural Affairs (Defra) and the Department of Energy and Climate Change (DECC) under licence from the Met Office, UKCIP, British Atmospheric Data Centre, Newcastle University, University of East Anglia, Environment Agency, Tyndall Centre and Proudman Oceanographic Laboratory. These organisations give no warranties, express or implied, as to the accuracy of the UKCP09 and do not accept any liability for loss or damage, which may arise from reliance upon the UKCP09 and any use of the UKCP09 is undertaken entirely at the users risk. 


\section{REFERENCES}

[1] UNESCO "Recommendation concerning the Protection at National Level, of the Cultural and Natural Heritage," 1972, accessed on 9 March 2016: http://whc.unesco.org/en/conventiontext/

[2] Drdácký, M., Binda, L., Herle, I., Lanza, L. G., Maxwell, I. and Pospíšil, S., "Protecting the cultural heritage from natural disasters,” IP/B/CULT/IC/2006_163, Brussels, European Parliament, 120 pp. (2007).

[3] Cigna, F., Tapete, D. and Lee, K., "Geohazards affecting UNESCO WHL sites in the UK observed from geological data and satellite InSAR," Proceedings of the Fourth International Conference on Remote Sensing and Geoinformation of the Environment (RSCy2016), 4-8 April 2016, Paphos, Cyprus, 10 pp. (2016).

[4] "PROTHEGO: PROTection of European Cultural HEritage from GeO-hazards", accessed on 9 March 2016, http://www.prothego.eu/

[5] "Derwent Valley Mills World Heritage Site Management Plan 2014-2019", accessed on 9 March 2016, http://www.derwentvalleymills.org/wp-content/uploads/2014/12/DVM_WHS_Management_MgmtPlanPDF.pdf

[6] "UNESCO World Heritage List", accessed on 9 March 2016, http://whc.unesco.org/en/list/

[7] "The Derwent Valley Mills, Boundaries of the World Heritage Site", accessed on 9 March 2016, http://www.derwentvalleymills.org/derwent-valley-mills-conservation/world-heritage-site-boundaries/

[8] Howard, A. J., Knight, D., Coulthard, T., Hudson-Edwards, K. A., Kossoff, D. and Malone, S., "Assessing riverine threats to heritage assets posed by future climate change through a geomorphological approach and predictive modelling in the Derwent Valley Mills WHS, UK," Journal of Cultural Heritage (2015).

[9] Intermap, "Intermap Product Handbook \& Quick Start Guide. Edit Rules Edition, v.4.4.3," Intermap Technologies Inc., 157 pp. (2015).

[10] Smith, A., "Digital Geological Map of Great Britain, information notes, 2013," BGS Open Report OR/13/007, Nottingham, UK, 54 pp. (2013).

[11] Tye, A. M., Entwisle, D. E. and Newsham, R., "User Guide for the British Geological Survey Corrosivity (Ferrous) dataset," BGS Open Report OR/11/023, Nottingham, UK, 17 pp. (2011).

[12] Entwisle, D., Lawley, R., Tye, A. and Turner P. "User Guide for DiGMapPlus Engineering Properties: Sulfate and Sulfide Potential," BGS Open Report OR/15/054, Nottingham, UK, 15 pp. (2015).

[13] Foster, C., Pennington, C. V. L., Culshaw, M. G. and Lawrie, K., "The national landslide database of Great Britain: development, evolution and applications," Environmental Earth Sciences 66(3), 941-953 (2012).

[14] Booth, K. and Wildman, G. "Geological Indicators of Flooding: User Guidance Notes, 2010," BGS Open Report OR/10/064, Nottingham, UK, 10 pp. (2010).

[15] British Geological Survey, "BGS Data Products. Susceptibility to groundwater flooding. Explanatory notes for users," 4 pp. (2016).

[16] Lee, K. A. and Diaz-Doce. D., "User Guide for the British Geological Survey GeoSure dataset," BGS Internal Report OR/14/012, 17 pp. (2014).

[17] Met Office "UKCP09 Climate Projections," 2015, accessed on 23 March 2016, http://ukclimateprojections.metoffice.gov.uk

[18] IPCC "IPCC Special Report, Emissions Scenarios, Summary for Policymakers. A Special Report of IPCC Working Group III," Published for the Intergovernmental Panel on Climate Change, WMO, UNEP (2000).

[19] Allison, I., Bindoff, N. L., Bindschadler, R. A., et al. "The Copenhagen Diagnosis: Updating the World on the Latest Climate Science," University of New South Wales, Climate Change Research Centre (CCRC), Sydney, Australia (2009).

[20] Howard, A. J. and Knight, D. "Future Climate and Environmental Change within The Derwent Valley Mills World Heritage Site," Final Report, Project 6927, 202 pp. (2015).

[21] Croft, A. "Assessment of Heritage at Risk from Environmental Threat. Key Messages Report, in Partnership with English Heritage," Birmingham, UK, 44 pp. (2013).

[22] Pennington, C. V. L., Dijkstra, T. A., Lark, M., Dashwood, C., Harrison, A. M., Freeborough, K. A. and Reeves, H. J. "Antecedent precipitation as a potential proxy for landslide incidence in the UK," Proc. Third World Landslide Forum, Landslide Science for a Safer Geoenvironment 253-259 (2014).

[23] Harrison, A. M., Plim, J. F. M., Harrison, M., Jones, L. D. and Culshaw, M. G. "The relationship between shrink-swell occurrence and climate in south-east England," Proc. Geologists' Assoc. 123(4), 556-575 (2012). 